\title{
Genetic diversity in Mesoamerican populations of mahogany (Swietenia macrophylla), assessed using RAPDs
}

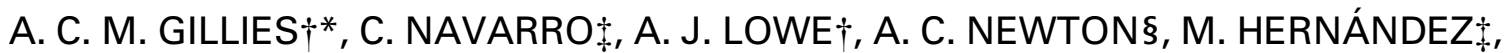 \\ J. WILSON $\dagger \&$ J. P. CORNELIUS \\ $\dagger$ Institute of Terrestrial Ecology, Bush Estate, Penicuik, Midlothian EH26 0QB, Scotland, UK, $\$$ Tropical Agricultural \\ Center for Research and Higher Education (CATIE), Turrialba 7170, Costa Rica and §Institute of Ecology \\ and Resource Management, University of Edinburgh, Darwin Building, Mayfield Road, Edinburgh EH9 3JU, \\ Scotland, UK
}

\begin{abstract}
Swietenia macrophylla King, a timber species native to tropical America, is threatened by selective logging and deforestation. To quantify genetic diversity within the species and monitor the impact of selective logging, populations were sampled across Mesoamerica, from Mexico to Panama, and analysed for RAPD DNA variation. Ten decamer primers generated 102 polymorphic RAPD bands and pairwise distances were calculated between populations according to Nei, then used to construct a radial neighbour-joining dendrogram and examine intra- and interpopulation variance coefficients, by analysis of molecular variation (AMOva). Populations from Mexico clustered closely together in the dendrogram and were distinct from the rest of the populations. Those from Belize also clustered closely together. Populations from Panama, Guatemala, Costa Rica, Nicaragua and Honduras, however, did not cluster closely by country but were more widely scattered throughout the dendrogram. This result was also reflected by an autocorrelation analysis of genetic and geographical distance. Genetic diversity estimates indicated that $80 \%$ of detected variation was maintained within populations and regression analysis demonstrated that logging significantly decreased population diversity $(P=0.034)$. This study represents one of the most wide-ranging surveys of molecular variation within a tropical tree species to date. It offers practical information for the future conservation of mahogany and highlights some factors that may have influenced the partitioning of genetic diversity in this species across Mesoamerica.
\end{abstract}

Keywords: conservation, genetic diversity, logging, RAPDs, Swietenia.

\section{Introduction}

Mahogany (Swietenia macrophylla King) (Meliaceae, Swietenioideae), is one of the most important timber species in world trade. It is principally used for making furniture and interior fittings and has been an important component in construction and ship building (Lamb, 1966). Its high economic value has resulted in overexploitation across its natural range and this, coupled with high deforestation rates, has led to the species becoming the focus of increasing concern (Newton et al., 1996). Recently, it has been proposed for inclusion in

*Correspondence and Present address: Sir Harold Mitchell Building, School of Environmental and Evolutionary Biology, University of St. Andrews, St. Andrews, Fife, KY16 9TH, Scotland, UK.

E-mail: acmg@st-andrews.ac.uk
Appendix II of the Convention on International Trade in Endangered Species (CITES), where the other species in the genus (S. humilis Zucc. and S. mahagoni (L.) Jacq.) are already listed (Rodan \& Campbell, 1996). Rates of mahogany overexploitation have been particularly alarming for Mesoamerica, where overall deforestation is estimated at around $4 \%$ annually (Myers, 1989) and a large proportion of the mahogany-containing forests have already been lost. Thus, there is an urgent need for development of sustainable management and conservation strategies for the remaining fragmented populations of $S$. macrophylla.

Swietenia macrophylla is a large, deciduous, tropical tree, with a broad and often emergent crown. It is able to reach a height of $40 \mathrm{~m}$, a diameter at breast height of over $2 \mathrm{~m}$ and may live for several centuries. The species 
is very widely distributed, stretching from southern Mexico to the southern Amazon basin in Brazil (Mayhew \& Newton, 1998). It inhabits both wet and dry forests (rainfall typically $1000-2500 \mathrm{~mm}$ ) and is found on a range of soils up to $1400 \mathrm{~m}$ altitude (Whitmore, 1983). As with many tropical tree species, the density of mahogany trees is typically fewer than one individual per hectare, although densities of up to eight trees per hectare have also been recorded. Mahogany is monoecious, with insect-pollinated (bees, moths and thrips), unisexual flowers. Pollination experiments indicate that it may be self-incompatible and a likely obligate outbreeder (Mayhew \& Newton, 1998). Seeds are winged, but relatively heavy and tend to fall close to the maternal tree (32-36 m median distance), although a maximum dispersal distance of over $80 \mathrm{~m}$ has been estimated by Gullison et al. (1996) for trees in a Bolivian population.

Genetic diversity is essential to the long-term survival of tree species. Without it there may be a risk of extinction because of lack of adaptive ability (Hamrick, 1994). In the light of the 1992 UNCED Rio conference (Harper \& Hawksworth, 1995), and general increased awareness of high deforestation rates in the tropics, considerable effort is being channelled into increasing our understanding of the extent and distribution of genetic diversity within tree species, for effective conservation and management strategies. Most analyses have been based on allozyme data and concentrate on temperate and boreal species, particularly conifers. In a recent review, Hamrick (1994) outlined a number of life-history traits that affect the partitioning of genetic diversity in tree species. Four general observations are apparent from his findings. First, tropical tree species, on average, display lower levels of variation than temperate trees. Secondly, species with a widespread geographical distribution tend to display greater diversity than those of a more limited range. Thirdly, predominantly outcrossing taxa maintain higher levels of genetic diversity than those that are primarily autogamous. Finally, selfing species tend to show a high degree of population substructuring, with diversity maintained among rather than within populations. The opposite is generally observed in outcrossing taxa.

In recent years, a variety of DNA-based techniques have been employed to study genetic variation in tree species (e.g. RAPD, AFLPs, SSRs and CAPS). Advantages of these methods over isozymes include their increased saturation of the genome and therefore better representation of the variation present within species (Storfar, 1996). RAPD is a very useful DNA-based method for initial assessment of genetic diversity in plant species, owing to its technical ease and speed and the wide availability of universal primers (Gillies et al., 1997). Despite these practical advantages, however, its value in diversity studies has been questioned, owing to the dominant nature of the bands, which can lead to the underestimation of recessive allele frequencies (Szmidt et al., 1996). This potential skewing can be reduced by examining a large number of RAPD loci (more than 30) and using data analysis techniques, such as that described by Lynch \& Milligan (1994), that compensate for the underestimation of the recessive allele when calculating allele frequencies.

The aim of the present investigation was to use RAPD to quantify intraspecific genetic variation in S. macrophylla populations across Mesoamerica. Results were also used in an attempt to identify factors that may have influenced the partitioning of genetic diversity within the species across this region.

\section{Materials and methods}

\section{Plant material}

Leaf material was collected from 420 mature mahogany trees from 20 populations located in seven Mesoamerican countries and three geographical regions (Table 1, Fig. 1). Selected populations were heterogeneous for habitat type, population density and degree of exploitation (Tables 1 and 2), and populations located within the same geographical region did not necessarily share environmental attributes. Populations were located using local knowledge and previous reconnaissance. A neighbourhood size of $2.5 \mathrm{~km}$ radius was adopted as a working definition of a population and populations within similar areas were separated by a minimum of $5 \mathrm{~km}$. Trees were sampled along a linear transect within each population, until a maximum sample size of 65 , or the end of the forest block, was reached. Only mature trees (d.b.h. $>80 \mathrm{~cm}$ ) were selected and the minimum distance between sampled trees was set as $100 \mathrm{~m}$, to reduce the chance of sampling closely related individuals. One of the sampled populations was a planted botanic garden (Lancetilla, Honduras). Data from this site were included only in the diversity analysis to assess the merits of artificially planting mahogany for the conservation of diversity within the genus.

Leaf samples were silica-gel dried, then air-freighted to Scotland for analysis. Herbarium specimens were prepared for a subset of the individuals and deposited in herbaria at CATIE, the National Museum of Costa Rica and the Pan-American Agricultural School in Zamorano, Honduras. Collection numbers of herbarium specimens are available from the authors on request. 
Table 1 Swietenia macrophylla populations in the analysis

\begin{tabular}{|c|c|c|c|c|c|c|c|c|c|}
\hline Country $\dagger$ & Population & $\begin{array}{l}\text { Latitude } \\
\qquad\left({ }^{\circ} \mathrm{N}\right)\end{array}$ & $\begin{array}{l}\text { Longitude } \\
\qquad\left({ }^{\circ} \mathrm{W}\right)\end{array}$ & $\begin{array}{l}\text { Altitude } \\
\quad(\mathrm{m})\end{array}$ & $\begin{array}{c}\text { Mean } \\
\text { annual } \\
\text { precipitation } \\
(\mathrm{mm})\end{array}$ & $\begin{array}{c}\text { Mean } \\
\text { annual } \\
\text { temperature } \\
\left({ }^{\circ} \mathrm{C}\right)\end{array}$ & $\begin{array}{l}\text { Sample } \\
\text { size }(N)\end{array}$ & $\begin{array}{l}\text { Distance between } \\
\text { population and point } \\
\text { of reference for } \\
\text { meteorological } \\
\text { data }(\mathrm{km})\end{array}$ & $\begin{array}{l}\text { Source of } \\
\text { metereological data }\end{array}$ \\
\hline \multirow[t]{3}{*}{ Guatemala [YP] } & Bethel & 16.90 & 90.91 & 125 & 1800 & 27 & 42 & 50 & F.A.O. (1995) \\
\hline & Tikal & 16.85 & 90.93 & 250 & 1955 & 28 & 34 & 60 & F.A.O. (1995) \\
\hline & La Técnica & 16.91 & 90.93 & 125 & 1800 & 27 & 45 & 60 & F.A.O. (1995) \\
\hline \multirow[t]{2}{*}{ Honduras [CZ] } & Corrales & 15.51 & 85.95 & 650 & 3278 & 22 & 9 & 60 & F.A.O. (1995) \\
\hline & Lancetilla & 15.74 & 85.46 & 40 & 3278 & 25 & 35 & 10 & F.A.O. (1995) \\
\hline \multirow[t]{4}{*}{ Costa Rica [CZ] } & Marabamba & 10.97 & 84.69 & 50 & 2885 & 24 & 65 & 0 & Bolaños \& Watson (1993) \\
\hline & San Emilio & 10.97 & 84.77 & 30 & 2885 & 24 & 10 & 0 & Bolaños \& Watson (1993) \\
\hline & Caño Negro & 10.94 & 84.71 & 55 & 2885 & 24 & 12 & 0 & Bolaños \& Watson (1993) \\
\hline & Playeulas & 10.92 & 84.69 & 35 & 2885 & 24 & 4 & 0 & Bolaños \& Watson (1993) \\
\hline \multirow[t]{2}{*}{ Panama $[\mathrm{P}]$} & Quintin & 8.26 & 78.27 & 350 & 2500 & 26 & 14 & 0 & Atlas of Panama \\
\hline & Punta Alegre & 8.05 & 78.23 & 10 & 2500 & 26 & 8 & 0 & Atlas of Panama \\
\hline Nicaragua $[\mathrm{CZ}]$ & Terciopelo & 14.01 & 83.94 & 60 & 2750 & 24 & 26 & 0 & Salas \& Juan (1993) \\
\hline \multirow[t]{5}{*}{ Belize [YP] } & New Maria & 16.82 & 89.00 & 600 & 2900 & 22 & 13 & 0 & Atlas of Belize \\
\hline & San Pastor & 16.71 & 88.97 & 600 & 2900 & 22 & 18 & 0 & Atlas of Belize \\
\hline & Las Cuevas & 16.72 & 89.00 & 600 & 2900 & 22 & 9 & 0 & Atlas of Belize \\
\hline & Grano de Oro & 16.72 & 89.02 & 600 & 2900 & 22 & 16 & 0 & Atlas of Belize \\
\hline & Rio Bravo & 17.84 & 89.03 & 50 & 1700 & 27 & 29 & 0 & Atlas of Belize \\
\hline \multirow[t]{3}{*}{ Mexico [YP] } & San Felipe & 18.76 & 88.49 & 50 & 1300 & 25 & 16 & 1 & K. Wightman (pers. comm.) \\
\hline & Madrazo & 18.03 & 89.24 & 150 & 2000 & 26 & 4 & 1 & K. Wightman (pers. comm.) \\
\hline & Naranjal & 19.37 & 88.46 & 50 & 1200 & 24 & 11 & 1 & K. Wightman (pers. comm.) \\
\hline
\end{tabular}




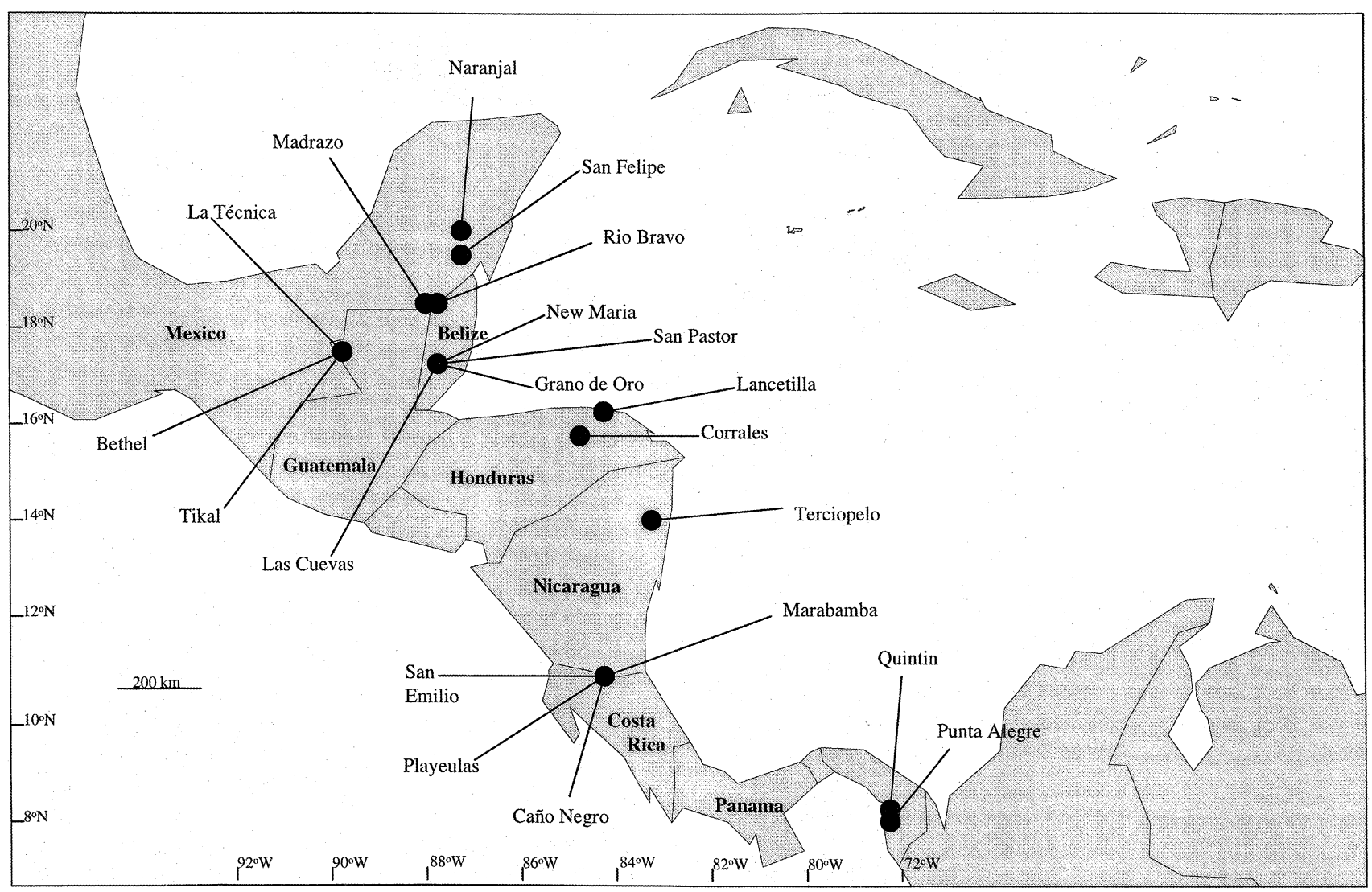

Fig. 1 Locations of the Swietenia macrophylla populations examined in this study.

\section{Experimental procedures}

Total genomic DNA was extracted from the dried leaf material, using a modified CTAB procedure (Gillies et al., 1997), and purified with spin bind filters (Hybaid), according to manufacturer's instructions. $25 \mu \mathrm{L}$ PCR amplification mixtures contained: $250 \mu \mathrm{M}$ of each of dATP, dTTP, dCTP and dGTP (GIBCO BRL), 1 unit Dynazyme (Flowgen Ltd), 1/10th volume $10 \times$ Dynazyme buffer (supplied with the enzyme), $2 \mu \mathrm{M}$ primer (OPB-02, OPB-03, OPB-05, OPB-07, OPB-10, OPB-13, OPB-16, OPB-17, OPB-18, OPB-19: Operon Technologies Ltd), $2.5 \mathrm{~mm} \mathrm{MgCl}_{2}$ (Sigma), 1-3 ng of DNA and sterile, distilled, deionized water to make up the final volume. The reaction mixture was overlaid with $40 \mu \mathrm{L}$ sterile mineral oil and tubes were placed inside the heating plate of a Perkin Elmer Cetus Thermal Cycler. Thermal cycling conditions were optimized to an initial denaturation at $94^{\circ} \mathrm{C}$ for $3 \mathrm{~min}$, followed by 45 cycles of $30 \mathrm{~s}$ at $94^{\circ} \mathrm{C}$ (denaturation), $45 \mathrm{~s}$ at $36^{\circ} \mathrm{C}$ (annealing) and 2 min at $72^{\circ} \mathrm{C}$ (extension). A final 4 min at $72^{\circ} \mathrm{C}$ ensured full extension of all amplified products. Results were visualized by ultraviolet (UV) transillumination, after separation in $2 \%$ agarose gels containing
$0.5 \mu \mathrm{g} \mathrm{mL} \mathrm{L}^{-1}$ ethidium bromide. Ten per cent of each primer/accession combination was repeated to ensure reproducibility of results, which was $100 \%$ in all instances.

\section{Data analysis}

Presence/absence of each scorable RAPD fragment was recorded in a binary data matrix and POPGENE v1.2 (Yeh, 1997) used to calculate the frequency of polymorphic bands in each population.

Genetic distances between populations were calculated, according to Nei (1972) as:

$D=\log _{\mathrm{e}}\left(J_{\mathrm{XY}} / J_{\mathrm{X}} J_{\mathrm{Y}}\right)$,

where $J_{\mathrm{XY}}, J_{\mathrm{X}}$ and $J_{\mathrm{Y}}$ are the arithmetic means of $j_{\mathrm{XY}}$, $j_{\mathrm{X}}$ and $j_{\mathrm{Y}}$, respectively, and $j_{\mathrm{XY}}=\Sigma x_{i} y_{i}, j_{\mathrm{X}}=\Sigma x_{i}^{2}$ and $j_{\mathrm{Y}}=\Sigma y_{i}^{2}$, where $x_{i}$ and $y_{i}$ represent the frequencies of the $i$ th allele in populations $\mathrm{X}$ and $\mathrm{Y}$. A radial neighbour-joining (NJ) dendrogram was then constructed from these distances, using PHYLIP (Felsenstein, 1993) and TREeVIEW 1.3 (Page, 1996). The number of shared fragments was also examined as a function of

(C) The Genetical Society of Great Britain, Heredity, 83, 722-732. 
geographical distance, using NAC for the Apple MacIntosh $^{\mathrm{TM}}$ (Number of Alleles in Common, Hamrick et al., 1993). Only RAPD fragments that were present at frequencies of between 0.3 and 0.5 in the overall sample were included in the autocorrelation analysis, as those of very high or low frequency were unlikely to be informative.

An analysis of molecular variation (AMOvA) was conducted to examine significant differences between the following grouped variance components: (i) within populations; (ii) between populations within geographical regions (as defined in Table 1); and (iii) between regions (winAmova 1.5, Excoffier et al., 1992). Shannon's diversity estimate (King \& Schaal, 1989) was calculated for each population as:

$H_{\mathrm{o}}=\sum P_{i} \cdot \log _{2} P_{i}$

where $P_{i}$ is the frequency of the $i$ th RAPD band. The between-population diversity component was calculated as $\left(H_{\mathrm{sp}}-H_{\mathrm{pop}}\right) / H_{\mathrm{sp}}$, where $H_{\mathrm{sp}}$ is the total diversity detected in all populations and $H_{\text {pop }}$ the mean withinpopulation diversity value. The proportion evident within populations was calculated as $H_{\mathrm{pop}} / H_{\mathrm{sp}}$. To allow direct comparisons between all populations, 10 individuals were taken at random from each.

The influence of precipitation, altitude, proximity to Pleistocene refugia, logging intensity and population density on genetic diversity estimates within populations was examined by means of single regression analyses, using MINITAB version 11.21. Logging was scored on a scale of $0.00-0.60$ (i.e. the $\log$ of $1-4$, because the scale is not linear), where 0.00 (1) indicated virgin forest, 0.30 (2) a lightly logged forest, 0.48 (3) a moderately logged forest and 0.60 (4) a heavily logged forest (Table 2). Scoring was based on visual assessments made during the collecting expeditions, and is therefore likely to reflect recent rather than ancient logging activity. Proximity to the nearest Pleistocene rainforest refugium in Belize, Honduras and near Panama (according to Toledo, 1981) was estimated, in metres, using a map (Table 2).

\section{Results}

One hundred and two polymorphic RAPD fragments were generated using 10 random decamer primers. The assumed homology of comigrating fragments was not tested in this present study. However, in the light of other research that has examined intraspecific fragment homology, and found it to be high (e.g. $79.1 \%$ in Helianthus species; Rieseberg, 1996), it was considered that the technique would be reliable for studying intraspecific variation in S. macrophylla.
Table 2 Details of the density of sampled populations of Swietenia macrophylla, the degree of disturbance within each and their distance from the nearest Mesoamerican Pleistocene refugium

\begin{tabular}{lccc}
\hline Population & $\begin{array}{c}\text { Density } \\
\text { (trees ha }^{-1} \text { ) }\end{array}$ & $\begin{array}{c}\text { Logging } \\
\text { intensity }\end{array}$ & $\begin{array}{c}\text { Distance from } \\
\text { refugium }(\mathrm{km})\end{array}$ \\
\hline Bethel & 0.2 & 0.48 & 10 \\
Tikal & 0.8 & 0.00 & 10 \\
La Técnica & 2.0 & 0.00 & 10 \\
Corrales & 2.0 & 0.30 & 380 \\
Marabamba & 0.5 & 0.48 & 750 \\
San Emilio & 2.5 & 0.30 & 750 \\
Caño Negro & 2.5 & 0.30 & 750 \\
Playeulas & 0.5 & 0.30 & 750 \\
Quintin & 0.1 & 0.00 & 30 \\
Punta Alegre & 0.1 & 0.48 & 30 \\
Terciopelo & 0.6 & 0.60 & 560 \\
New Maria & 1.0 & 0.60 & 1 \\
San Pastor & 2.5 & 0.60 & 1 \\
Las Cuevas & 1.5 & 0.60 & 1 \\
Grano de Oro & 2.5 & 0.60 & 1 \\
Rio Bravo & 2.5 & 0.60 & 190 \\
San Felipe & 0.6 & 0.48 & 380 \\
Madrazo & 0.5 & 0.48 & 190 \\
Naranjal & 2.0 & 0.00 & 400 \\
\hline
\end{tabular}

$\dagger 0.00=$ virgin forest; $0.30=$ lightly logged forest;

$0.48=$ disturbed forest; $0.60=$ heavily disturbed forest.

The number of polymorphic fragments scored per primer varied from eight (OPB-03) to 12 (OPB-18). The number of polymorphic fragments in each population also varied, with those from Guatemala possessing the greatest number (100-101), and those from Mexico possessing the least (60-90). No fragment was unique to a particular population. However, a number of bands, e.g. OPB-07.03, were found to be absent from populations in Nicaragua and Honduras, whereas others (e.g. OPB-07.1) were present only in those from Guatemala. Other fragments occurred at low frequency in a few populations from two or three countries, e.g. OPB-03.1 occurred at low frequency in populations from Guatemala (0.02-0.07), Nicaragua (0.08) and Costa Rica (0.08-0.09).

Radial NJ clustering of populations resolved them into two main groups (Fig. 2). Cluster A was composed of all three populations from Mexico (Naranjal, Madrazo and San Felipe) forming one distinct group, with the five populations collected in Belize (Las Cuevas, New Maria, Rio Bravo, San Pastor and Grano de Oro), one from Panama (Quintin) and one from Costa Rica (San Emilio) in another group. Cluster B comprised all three populations from Guatemala (La Técnica, Bethel and Tikal), three of the four from Costa Rica (Caño Negro, Playuelas and Marabamba), the single 


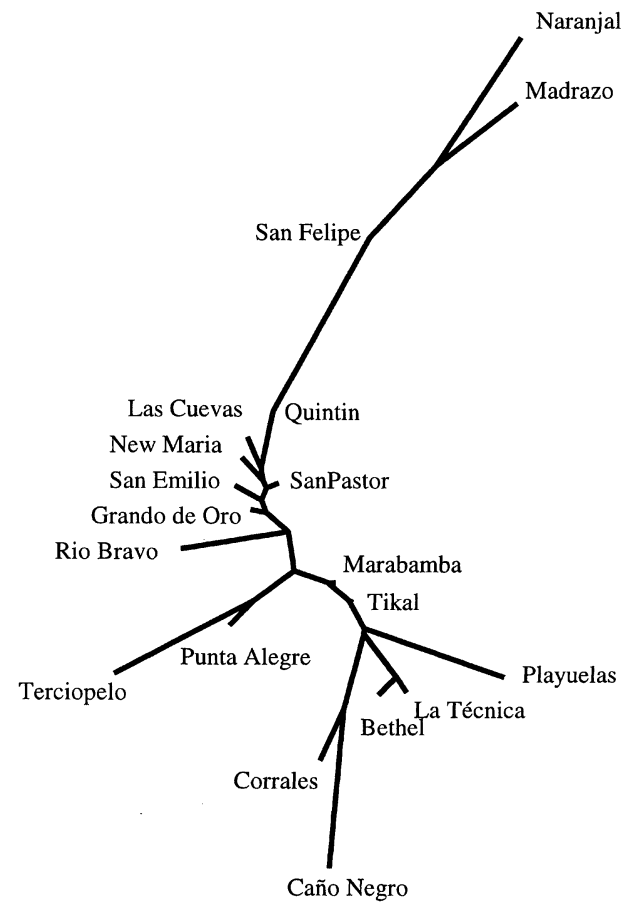

0.1

Fig. 2 Radial neighbour-joining (NJ) dendrogram, showing clustering of the 19 Swietenia macrophylla populations.

population from each of Honduras (Corrales) and Nicaragua (Terciopelo) and one of the two from Panama (Punta Alegre). Unlike those in Cluster A, populations in Cluster B were not divided into subgroups according to country but mixed together throughout the cluster; indicating that a greater degree of variation is present in these populations than those from Mexico and Belize.

Estimation of variance components by AMOvA (Table 3), revealed that most of the total variance was attributable to variation within populations $(87.43 \%$, $P<0.004)$. However, a significant amount was also attributed to variation between populations within the geographical regions (i.e. Yucatán Peninsula, Central Zone and Panama, $12.01 \%, P<0.004)$. The amount of variance attributable to variation between regions was not significant $(0.57 \%, P=0.38)$ and $\phi_{\mathrm{ST}}$ was estimated to be 0.126 .

Results of the analysis examining autocorrelation between genetic and geographical distances are presented in Table 4. Similarities between individuals were inversely proportional to the geographical distance between them, up to $900 \mathrm{~km}$; with numbers of alleles in common (NAC) decreasing from $1.41 \pm 0.002$ (SE) for pairwise tests of trees $0 \mathrm{~km}$ apart, to $1.28 \pm 0.002$ for tests between trees $900 \mathrm{~km}$ apart. Similarity values then increased with increasing distance from $900 \mathrm{~km}$ to $1300 \mathrm{~km}$, as NAC increased from $1.28 \pm 0.002$ to $1.47 \pm 0.009$, and finally decreased again $(\mathrm{NAC}=$ $1.28 \pm 0.005)$ with increasing distance, up to a maximum of $1500 \mathrm{~km}$.

Table 4 Results of an autocorrelation analysis of genetic and geographical distance between Swietenia macrophylla individuals

\begin{tabular}{rrr}
\hline Distance units & \begin{tabular}{c} 
No. of \\
\multicolumn{3}{c}{ pairwise comparisons }
\end{tabular} \\
\hline 0 & 9715 & Mean NAC $\dagger$ \\
100 & 10821 & $1.41 \pm 0.002$ \\
200 & 8763 & $1.37 \pm 0.002$ \\
300 & 5050 & $1.37 \pm 0.002$ \\
400 & 5890 & $1.40 \pm 0.003$ \\
500 & 7251 & $1.37 \pm 0.002$ \\
600 & 4919 & $1.37 \pm 0.003$ \\
700 & 8330 & $1.40 \pm 0.002$ \\
800 & 11661 & $1.33 \pm 0.002$ \\
900 & 5096 & $1.28 \pm 0.002$ \\
1000 & 896 & $1.40 \pm 0.007$ \\
1100 & 182 & $1.41 \pm 0.014$ \\
1300 & 784 & $1.47 \pm 0.009$ \\
1400 & 2478 & $1.36 \pm 0.004$ \\
1500 & 1600 & $1.28 \pm 0.005$ \\
\hline
\end{tabular}

$\uparrow \mathrm{NAC}$, number of alleles in common.

Table 3 Analysis of molecular variance for the 20 populations of Swietenia macrophylla

\begin{tabular}{lcccccc}
\hline Source of variation & d.f. $\dagger$ & SSD $\$$ & MSD & $\begin{array}{c}\text { Variance } \\
\text { component }\end{array}$ & $\begin{array}{c}\text { \% Total } \\
\text { variation }\end{array}$ & $P$-value \\
\hline Between regions & 2 & 64.29 & 32.14 & 0.11 & 0.57 & 0.38 \\
$\begin{array}{l}\text { Between populations } \\
\text { within regions }\end{array}$ & 4 & 123.23 & 30.81 & 2.38 & 12.01 & $<0.004$ \\
\begin{tabular}{l} 
Within populations \\
\hline
\end{tabular} & 33 & 573.60 & 345.26 & 17.38 & 87.43 & $<0.004$ \\
\hline
\end{tabular}

$\dagger$ Degrees of freedom.

$\$$ Sum of squared deviations.

$\S$ Mean squared deviations.

(C) The Genetical Society of Great Britain, Heredity, 83, 722-732. 
Table 5 Genetic diversity estimates within populations of Swietenia macrophylla, calculated using Shannon's Diversity Index

\begin{tabular}{|c|c|c|c|c|c|c|c|c|c|c|c|}
\hline Population & OPB-02 & OPB-03 & OPB-05 & OPB-07 & OPB-10 & OPB-13 & OPB-16 & OPB-17 & OPB-18 & OPB-19 & $H_{\mathrm{o}}$ \\
\hline Quintin & 0.42 & 0.39 & 0.52 & 0.32 & 0.41 & 0.45 & 0.41 & 0.51 & 0.35 & 0.37 & 0.41 \\
\hline Bethel & 0.46 & 0.44 & 0.42 & 0.46 & 0.45 & 0.54 & 0.52 & 0.55 & 0.54 & 0.50 & 0.40 \\
\hline Playeulas & 0.43 & 0.39 & 0.30 & 0.44 & 0.54 & 0.45 & 0.44 & 0.46 & 0.37 & 0.47 & 0.38 \\
\hline Lancetilla & 0.48 & 0.36 & 0.39 & 0.20 & 0.53 & 0.44 & 0.49 & 0.45 & 0.37 & 0.51 & 0.38 \\
\hline Marabamba & 0.44 & 0.44 & 0.39 & 0.37 & 0.54 & 0.46 & 0.46 & 0.53 & 0.42 & 0.50 & 0.37 \\
\hline San Pastor & 0.31 & 0.39 & 0.33 & 0.26 & 0.37 & 0.46 & 0.32 & 0.50 & 0.30 & 0.31 & 0.36 \\
\hline San Felipe & 0.46 & 0.13 & 0.53 & 0.22 & 0.41 & 0.48 & 0.24 & 0.41 & 0.34 & 0.32 & 0.35 \\
\hline San Emilio & 0.29 & 0.38 & 0.35 & 0.21 & 0.45 & 0.41 & 0.45 & 0.46 & 0.35 & 0.35 & 0.35 \\
\hline Caño Negro & 0.48 & 0.29 & 0.30 & 0.22 & 0.57 & 0.52 & 0.52 & 0.50 & 0.44 & 0.45 & 0.34 \\
\hline Terciopelo & 0.45 & 0.37 & 0.34 & 0.24 & 0.50 & 0.45 & 0.48 & 0.48 & 0.40 & 0.25 & 0.35 \\
\hline Naranjal & 0.39 & 0.20 & 0.48 & 0.25 & 0.42 & 0.21 & 0.30 & 0.28 & 0.37 & 0.31 & 0.32 \\
\hline Las Cuevas & 0.26 & 0.34 & 0.26 & 0.25 & 0.31 & 0.37 & 0.26 & 0.36 & 0.24 & 0.30 & 0.32 \\
\hline Madrazo & 0.30 & 0.15 & 0.46 & 0.25 & 0.38 & 0.27 & 0.40 & 0.39 & 0.22 & 0.30 & 0.27 \\
\hline
\end{tabular}

Table 6 Partitioning diversity in Swietenia macrophylla into within- and between-population components, using Shannon's Diversity Index

\begin{tabular}{lcccc}
\hline Primer & $H_{\text {pop }}$ & $H_{\mathrm{sp}}$ & $H_{\text {pop }} / H_{\mathrm{sp}}$ & $\left(H_{\mathrm{sp}}-H_{\mathrm{pop}}\right) / H_{\mathrm{sp}}$ \\
\hline OPB-02 & 0.35 & 0.43 & 0.81 & 0.19 \\
OPB-03 & 0.25 & 0.37 & 0.68 & 0.32 \\
OPB-05 & 0.30 & 0.42 & 0.71 & 0.29 \\
OPB-07 & 0.24 & 0.36 & 0.67 & 0.33 \\
OPB-10 & 0.42 & 0.49 & 0.86 & 0.14 \\
OPB-13 & 0.40 & 0.50 & 0.80 & 0.20 \\
OPB-16 & 0.42 & 0.50 & 0.84 & 0.16 \\
OPB-17 & 0.40 & 0.49 & 0.82 & 0.18 \\
OPB-18 & 0.35 & 0.43 & 0.81 & 0.19 \\
OPB-19 & 0.43 & 0.50 & 0.86 & 0.14 \\
Mean & 0.36 & 0.45 & 0.80 & 0.20 \\
\hline
\end{tabular}

Diversity estimates for each population, calculated according to Shannon's Diversity Index, varied according to primer (Table 5); for example, OPB-05 and OPB-16 gave estimates of $H_{\mathrm{o}}=0.30$ and $H_{\mathrm{o}}=0.52$, respectively, for Caño Negro. Averaged over all primers, La Técnica (Guatemala) and Quintin (Panama) displayed the highest level of within-population diversity $\left(H_{\mathrm{o}}=0.41\right.$ for each) and Madrazo (Mexico) the lowest $\left(H_{\mathrm{o}}=0.27\right)$. The average diversity present within the species, $H_{\mathrm{sp}}$, was estimated to be 0.45 . Overall, the within-population component of genetic diversity was
Table 7 Regression analysis for factors that may influence genetic diversity within populations of Swietenia macrophylla

\begin{tabular}{|c|c|c|c|c|c|}
\hline Factor & d.f. $\dagger$ & SS: & $\begin{array}{l}\text { Variance } \\
\text { component }\end{array}$ & $P$-value & $\begin{array}{c}\text { Total } \\
\text { variation } \\
(\%)\end{array}$ \\
\hline $\begin{array}{l}\text { Proximity to } \\
\text { refugium }\end{array}$ & 1 & 0.0003 & 0.23 & 0.639 & 1.3 \\
\hline $\begin{array}{l}\text { Degree of } \\
\text { disturbance }\end{array}$ & 1 & 0.0057 & 5.35 & 0.034 & 23.9 \\
\hline Altitude & 1 & 0.0008 & 0.63 & 0.439 & 3.6 \\
\hline Precipitation & 1 & 0.0001 & 0.05 & 0.823 & 0.3 \\
\hline Longitude & 1 & 0.0013 & 1.00 & 0.332 & 5.6 \\
\hline Latitude & 1 & 0.0043 & 3.78 & 0.069 & 18.2 \\
\hline $\begin{array}{l}\text { Density } \\
\text { of trees }\end{array}$ & 1 & 0.0024 & 1.92 & 0.183 & 10.2 \\
\hline
\end{tabular}

$\dagger$ Degrees of freedom.

$\ddagger$ Sum of squares.

$80 \%$, whereas $20 \%$ was maintained between populations (Table 6).

The significance of a number of factors that may have influenced genetic diversity within populations was examined using regression analysis (Table 7). Results indicated that most of the variance between populations $(23.9 \%)$ was attributable to the effect of logging $(P=0.034)$, with increased logging resulting in a significant decrease in diversity. None of the other examined factors (i.e. proximity to Pleistocene refugia, altitude, 
precipitation, longitude, latitude and population density) appeared significantly to affect the extent of variation within populations.

\section{Discussion}

Most tropical tree species subject to previous genetic diversity analyses have been sampled over limited portions of their natural ranges. This current study is one of the few to consider molecular variation in a tropical tree species on a regional rather than local scale and therefore affords some comparison with the data available for broadly distributed temperate species.

Population diversity values for $S$. macrophylla $\left(H_{\mathrm{o}}=0.41-0.27\right)$ are somewhat lower than those already determined for other tree species using similar RAPD methodology. For example, Allnutt et al. (1999) obtained diversity estimates ranging between 0.42 and 0.56 for Chilean populations of Fitzroya cupressoides and Yeh et al. (1995) obtained values between 0.58 and 0.69 for Populus tremuloides. Total diversity in S. macrophylla $\left(H_{\mathrm{sp}}=0.45\right)$ was also less than determined in these earlier studies $\left(H_{\mathrm{sp}}=0.54\right.$ and 0.65 for $F$. cupressoides and $P$. tremuloides, respectively). This is somewhat surprising, given the extensive range of $S$. macrophylla, which might indicate that intraspecific diversity within it should be high (Hamrick \& Loveless, 1989). However, the species occurs at an average frequency of just 1.3 adult trees $\mathrm{ha}^{-1}$ in populations included in this study (Table 2). Hall et al. (1994) have demonstrated that tree species occurring at this density, or lower, can be less diverse than those that are more abundant. Interestingly, a recent study of diversity in Calliandra calothyrsus from Mesoamerica, using isozyme markers, also detected low levels of variation within populations (Chamberlain, 1998). Unfortunately, the study is not directly comparable with that reported here, because it was not performed using the same markers. However, Chamberlain suggested that the low level of diversity may have been caused by human disturbance. This may also partly explain the results obtained in this current work.

Partitioning diversity into its within- and betweenpopulation components indicated that $87.9 \%$ was maintained within populations (AMOVA). This value is similar to those obtained in other studies of outcrossing tree species using RAPD; for example, $97.4 \%$ of the variation evident in $P$. tremuloides was present within populations (Yeh et al., 1995). Isozyme studies in some other tropical trees also give similar values; for example, in Pentaclethra macroloba, $78.1 \%$ of diversity was maintained within populations (Hall et al., 1994) and 85\% within populations of Cordia alliodora (Chase et al., 1995). Data for S. macrophylla agree with the general observation that woody, perennial, outbreeding species maintain most of their variation within populations (Hamrick, 1994). Very little is known about the mating system of S. macrophylla. However, recent work on Bolivian populations has shown the species to be highly outcrossing (M. D. Loveless, pers. comm.), which is supported by the findings presented here.

A significant portion of diversity was also maintained between populations within the three geographical regions in Mesoamerica (i.e. Yucatán Peninsula, Central Zone and Panama; $12.01 \%, P<0.004$, Amova). This degree of differentiation is comparable with that observed in some other studies of outcrossing tree species; for example $16.4 \%$ of the variation in Eucalyptus globulus was maintained between populations within regions in Australia (Nesbitt et al., 1995). However, it is somewhat greater than values obtained in most other studies; for example, the average between-population differentiation for 25 oak species was just 7\% (Kremer \& Petit, 1993). This greater degree of population differentiation in S. macrophylla implies limited gene flow, and could be explained by the behaviour of its insect pollinators, which may not travel great distances and remain localized within populations or regions. Furthermore, seed dispersal is also localized (Gullison et al., 1996).

These results, and the low $\phi_{\mathrm{ST}}$ value (0.126), do still suggest that a significant amount of gene flow is taking place between populations within geographical regions. However, this may only be a reflection of historical gene flow when populations were less fragmented. Widespread deforestation of Mesoamerica means that continuous pollen and seed flow is unlikely to be possible at the present time. An examination of diversity and breeding system in the next generation of mahogany is essential to our understanding of the effect of disturbance on the species; for example, M. D. Loveless and coworkers (pers. comm.) have studied outcrossing rates in one mahogany population before and after logging. They found that logging significantly reduced outcrossing, which has profound implications for future generations of S. macrophylla, should it continue unchecked.

Autocorrelation between genetic and geographical distance indicated that similarities of populations separated by up to $900 \mathrm{~km}$ were inversely proportional to the distance between them (Table 4). This negative correlation may reflect the gene flow taking place between individuals, because increased geographical distance usually results in increased isolation between populations and therefore reduced gene flow (Parker et al., 1997). Spatial genetic homogeneity within an area can, likewise, be attributed to the occurrence of considerable gene flow.

Similarities between populations increased with increasing geographical distance to $1300 \mathrm{~km}$ and finally 
decreased again at $1500 \mathrm{~km}$. This does not follow a pattern of isolation by distance and may result from similar environmental conditions, such as soil type, precipitation and the number of dry months, within these areas; for example, populations from Mexico, one of the driest areas in the study, are resolved together in a distinct subgroup of cluster $\mathrm{A}$, whereas populations in cluster $\mathrm{B}$ are from areas that tend to receive a higher level of rainfall (Table 1, Fig. 2). The final decrease in the similarity of RAPD profiles of populations separated by more than $1300 \mathrm{~km}$ may be because of still further reductions in gene flow. It is certain that the populations separated by this distance will have significant barriers, such as mountains, between them, resulting in reduced gene flow and differentiation.

With few exceptions, all populations in Cluster A of the $\mathrm{NJ}$ dendrogram originate either from Mexico or Belize. Cluster B consists of populations from Honduras, Costa Rica, Nicaragua, Guatemala and Panama. This difference between populations in Clusters A and B may reflect colonization from separate Pleistocene refugia. Toledo (1981) has located positions for eight putative refugia in Mexico, Belize and Guatemala, based upon species diversity and regions rich in endemism. It is generally accepted that rainforest species retreated to moist refugia when climate conditions cooled and dried during the last ice age. Forest species migrated out of the refugia and recolonized surrounding areas once climatic conditions improved. Populations in Cluster A may have been derived from individuals migrating out of a northern Mexican refugium, whereas the other populations may have been colonized from refugia in Belize and Guatemala or further south. However, further work, such as a phylogeographical study using chloroplast DNA markers, should be conducted to test this hypothesis.

Quintin, from Panama, has also resolved within Cluster A. This result is unexpected, given the considerable distance between Mexico and Panama (Fig. 1). One possible explanation may be that similarities between the populations are caused by comigration of nonhomologous RAPD bands (Rieseberg, 1996), although this theory needs to be tested. These similarities may also be caused by paralogous evolution or the wide range of variation evident across the species range.

Extensive deforestation and planting took place in what is now southern Mexico, Guatemala, Belize and Honduras during the time of the Mayan civilization, between AD 1 and 1300. Research has shown (Abrams et al., 1996), for example, that Meliaceae-type pollen was completely absent from one Mayan-occupied site, but that it subsequently recolonized once the site was abandoned. The Mayans completely destroyed large forested areas in order to establish their agriculture system. They also selectively cut down and planted key species, such as S. macrophylla, for timber and canoe building. The Mayans may therefore have played a significant role in the distribution of this species. This may provide another explanation why populations in Cluster A, with the exception of Quintin, are so different from the rest of the samples in the study, because it is conceivable that the Mayans may have transported seed from significant distances outside the area for planting purposes.

\section{The influence of logging on genetic diversity}

Documenting the effect of logging on diversity is difficult and few quantitative data currently exist. Most information is anecdotal and only extreme cases, such as extinction, can unequivocally demonstrate an effect (Ledig, 1992).

The biological effects of logging on a species range from severe structural damage, caused by the logging machinery as selected trees are cut down and removed, to total extinction. Significant increases in inbreeding, caused either by selfing or crossing between sibs, have also been recorded (Ledig, 1992). One consequence of inbreeding is that it may result in fixation of deleterious recessive alleles that are otherwise meshed in the heterozygous state in an outcrossing population. Increased inbreeding may also result in a reduction of the genetic diversity within populations. Overall, populations have a tendency to become less fit as the number and expression of deleterious genes increases as a result of inbreeding. Consequently, the population becomes less able to adapt to change and the risk of extinction is increased.

Logging appears to have had a detrimental effect on genetic diversity in mahogany, because it accounts for a significant portion of the total variance in this study (23.9\%; $P=0.034)$. Populations from Belize, for example, all have a long history of exploitation (Whitman et al., 1997), although they have been protected in national parks for the past 10 years (C. Navarro, pers. obs.). These populations exhibit lower genetic diversity than unlogged populations, e.g. La Técnica and Tikal from Guatemala. Quintin, in Panama, is also a highly diverse virgin forest fragment, surrounded by areas where the forest has been cut down. Moves should be made to protect this population before it also is destroyed. Other logged populations include Terciopelo in Nicaragua and the Mexican populations San Felipe, Naranjal and Madrazo. All of these maintain less variation than those disturbed to a lesser extent.

Interestingly, the Mexican samples in this study originate from close to the northern limit of the species range and maintain the lowest amount of within-population diversity. In addition to the effect of logging, this could 
result from the more extreme selection pressure, and edge effects such as drift and fixation, that may be evident at the periphery of the species range (Hall et al., 1994).

\section{Conservation of mahogany}

Although recommendations for conservation based upon the findings of this survey should be treated with caution until several other investigations have been completed (e.g. provenance trials set up using seeds from the populations considered here), this study has identified several mahogany populations that may warrant specific conservation and further study. Some of the most noteworthy include the genetically distinct populations from Mexico, which maintain some of the lowest levels of diversity. A second area is the threatened region in Panama, which contains one of the most diverse populations in the study (Quintin).

Results have also shown that the diversity contained within mahogany is distributed across the whole of its range. Preservation of this diversity in its entirety will require the development of a comprehensive conservation strategy, something that is currently lacking. It is of interest to note that some of the RAPD frequencies measured varied according to country. Although this is without biological meaning per se it may be useful in the development of specific conservation programmes within countries.

One possible approach for ex situ conservation of S. macrophylla could be its inclusion in botanic gardens and the development of seed orchards. For example, the Lancetilla Botanic Garden in Honduras contains trees grown from seed collected along the Honduran Atlantic coast and is highly diverse (ranking sixth out of 20 in Table 5, whereas Corrales, a natural population from Honduras, ranks fifteenth). Despite the serious problems caused by the shoot borer in Mesoamerica (Mayhew \& Newton, 1998), this may still be an effective method of conservation as the trees would not be grown for their timber.

Results indicate that selective logging significantly reduces genetic diversity within $S$. macrophylla. This could pose a serious threat to the future viability of the species if it continues unchecked. Effective conservation and sustainable management programmes for the species are an urgent priority.

\section{Acknowledgements}

This work is the result of a collaboration between the Institute of Terrestrial Ecology and the Tropical Agronomic Center for Higher Education and Research (CATIE; Costa Rica). It is partly supported by funding from the European Commission, under framework III of DGXII, contract number TS3*CT94-0316 and partly by the Natural Environment Research Council. We would like to acknowledge Drs P. Kanowski, D. Boshier and A. Pottinger from the Oxford Forestry Institute, for their enthusiastic support. Grateful thanks are also extended to $\mathrm{Dr}$ R. Leakey, for his valuable comments on this manuscript, and to Mr R. I. Smith, for his help with the statistical analysis.

\section{References}

ABRAMS, E. M., FRETER, A., RUE, D. J. AND WINGARD, J. D. 1996. The role of deforestation in the collapse of the Late Classic Copán Maya State. In: Sponsel, L. E., Headland, T. N. and Bailey, R. C. (eds) Tropical Deforestation: The Human Dimension, pp. 55-75. Columbia University Press, New York.

ALlNUtT, T. R., NEWTON, A.C., LARA, A., ARMESTO, J. J., PREMOLI, A., VERAGA, R. AND GARDNER, M. 1999. Genetic variation in Fitzroya cupressoides (alerce), a threatened South American conifer. Mol. Ecol., 8, 975-987.

BOLAÑos, R. AND WATSON, v. 1993. Mapa ecológico de Costa Rica. Digital map. Centro Científico Tropical, San Jose, Costa Rica.

CHAMBerlain, J. R. 1998. Isozyme variation in Calliandra calothyrsus (Leguminosae): its implications for species delimitation and conservation. Am. J. Bot., 85, 37-47.

CHASE, M. R., BOSHIER, D. H. AND BAWA, K. S. 1995. Population genetics of Cordia alliodora (Boraginaceae), a neotropical tree. 1. Genetic variation in natural populations. Am. J. Bot., 82, 468-475.

EXCOFfIER, L., SMOUSE, P. E. AND QuATtro, J. M. 1992. Analysis of molecular variance inferred from metric distances among DNA haplotypes: application to human mitochondrial DNA restriction data. Genetics, 131, 479-491.

F. A. O. 1995. Agroclimatological Data for Latin America and the Caribbean. Plant Production and Protection Series, no. 24. Food and Agriculture Organization of the United Nations, Rome.

FELSENSTEIN, J. 1993. PHYLIP (Phylogeny Inference Package), version 3.5C. Distributed by the author. Department of Genetics, University of Washington, Seattle, WI.

Gillies, A. C. M., CORNelius, J. P., NeWton, A. C., NAVARro, C., HERNÁNDEZ, M. AND WILSON, J. 1997. Genetic variation in Costa Rican populations of the tropical timber species Cedrela odorata L. assessed using RAPDs. Mol. Ecol., 6, 1133-1146.

Gullison, R. E., PANFil, S. N., Strouse, J. J. AND Hubbell, S. P. 1996. Ecology and management of mahogany (Swietenia macrophylla King) in the Chimanes Forest, Beni, Bolivia. Bot. J. Linn. Soc., 122, 9-34.

HAll, P., CHASE, M. R. AND BAWA, K. S. 1994. Low genetic variation but high population differentiation in a common tropical forest tree species. Conserv. Biol., 8, 471-482.

HAMRICK, J. L. 1994. Genetic diversity and conservation in tropical forests. In: Drysdale, R. M., John, S. E. T. and Yapa, A. C. (eds) Proceedings of the International Symposium on Genetic Conservation and Production of 
Tropical Forest Tree Seed, pp. 1-9. ASEAN-Canada Forest Tree Seed Centre Project, Muak-Lek, Saraburi, Thailand.

HAMRICK, J. L. AND LOVELESS, M. D. 1989. The genetic structure of tropical tree populations: associations with reproductive biology. In: Bock, J. H. and Linhart, Y. B. (eds) The Evolutionary Biology of Plants, pp. 129-146. Westview Press, Boulder, CO.

HAMRICK, J. L., MURAWSKI, D. A. AND NASON, J. D. 1993. The influence of seed dispersal mechanisms on the genetic structure of tropical tree populations. Vegetetio, 107, 281-287.

HARPER, J. L. AND HAWKSWORTH, D. L. 1995. Preface. In: Hawksworth, D. L. (ed.) Biodiversity Measurement and Estimation, pp. 5-12. The Royal Society. Chapman \& Hall, London.

KING, L. M. AND SCHAAL, B. A. 1989. Genotypic variation within asexual lineages of Taraxacum officinale. Proc. Natl. Acad. Sci. U.S.A., 87, 998-1002.

KREMER, A. AND PETIT, R. J. 1993. Gene diversity in natural populations of oak species. Ann. Sci. For., 50, 1865-2025.

LAMB, F. B. 1966. Mahogany of Tropical America: its Ecology and Management. The University of Michigan Press, Ann Arbor, Chicago, PA.

LEDIG, F. T. 1992. Human impacts on genetic diversity in forest ecosystems. Oikos, 63, 87-108.

LYNCH, M. AND MILligAN, B. G. 1994. Analysis of population genetic structure with RAPD markers. Mol. Ecol., 3, 91-99.

MAYHEW, J. E. AND NEWTON, A. C. 1998. The Silviculture of Mahogany. CABI Publishing, Oxford.

MYERS, N. 1989. Deforestation Rates in Tropical Forests and Their Climatic Implications. Friends of the Earth, London.

NEI, M. 1972. Genetic distance between populations. Am. Nat., 106, 283-292.

NESBitT, K. A., POTTS, B. M., VAILlANCOURT, R. E., WEST, A. K. AND REID, J. B. 1995. Partitioning and distribution of RAPD variation in a forest tree species, Eucalyptus globulus (Myrtaceae). Heredity, 74, 628-637.

NEWTON, A. C., CORNEliUs, J. P., BAKer, P., GILlies, A. C. M., HERNÁNDEZ, M., RAMNARINE, R. ET AL. 1996. Mahogany as a genetic resource. Bot. J. Linn. Soc., 122, 61-73.
PAGE, R. D. M. 1996. TREeVIEW (Win16), version 1.30. Distributed by the author. http://taxonomy.zoology.gla.ac.uk/rod/ rod.html

PARKer, K. C., HAMrick, J. L., PALMER, A. J. AND STACY, E. A. 1997. Allozyme diversity in Pinus virginiana (Pinaceae): intraspecific and interspecific comparisons. Am. J. Bot., 84, 1372-1382.

RIESEBERG, L. 1996. Homology among RAPD fragments in interspecific comparisons. Mol. Ecol., 5, 99-105.

RODAN, B. D. AND CAMPBEll, F. T. 1996. CITES and the sustainable management of Swietenia macrophylla King. Bot. J. Linn. Soc., 122, 83-87.

SAlas, E. AND JUAN, B. 1993. Arboles de Nicaragua. IRENA, Nicaragua.

STORFAR, A. 1996. Quantitative genetics: a promising approach for the assessment of genetic variation in endangered species. Trends Ecol. Evol., 11, 343-348.

SZMIDT, A. E., WANG, X.-R. AND LU, M.-Z. 1996. Empirical assessment of allozyme and RAPD variation in Pinus sylvestris (L.) using haploid tissue analysis. Heredity, 76, 412-420.

TOLEDO, V. M. 1981. Pleistocene changes of vegetation in tropical Mexico. In: Prance, G. T. (ed.) Biological Diversification in the Tropics, pp. 93-111. Columbia University Press, New York.

WhitMAN, A. A., BROKAw, N. V. L. AND HAGAN, J. M. 1997. Forest damage caused by selective logging of mahogany (Swietenia macrophylla) in northern Belize. Forest Ecol. Manag., 92, 87-96.

WHITMORE, J. L. 1983. Swietenia macrophylla and S. humilis (Caoba, mahogany). In: Janzen, D. H. (ed.) Costa Rica Natural History, pp. 331-333. University of Chicago Press, Chicago, IL.

YEH, F. C. 1997. POPGENE, version 1.21. Distributed by the author. http://www.ualberta.ca/ fyeh/fyeh/.

YEH, F. C., CHONG, D. K. X. AND YANG, R.-C. 1995. RAPD variation within and among natural populations of trembling aspen (Populus tremuloides) from Alberta. J. Hered., 86, 454- 460 . 